\title{
Seroprevalence of Hepatitis E IgG Antibodies Among Voluntary Blood Donors in a Tertiary Hospital
}

\author{
C P Luck ${ }^{1}$, Jamunarani Srirangaramasamy ${ }^{1 *}$, Duraipandian Jeyakumari ${ }^{2}$, Madasamy Balamurugan ${ }^{1}$ \\ Aruna Padmavathi $V^{1}$ and Kolsamma Nasrin ${ }^{1}$
}

Department of Pathology, Tagore Medical college and Hospital, Rathinamangalam, Chennai, Tamilnadu, India

Department of Microbiology, Tagore Medical college and Hospital, Rathinamangalam, Chennai, Tamilnadu, India

\begin{abstract}
Background: Transfusion safety is a major concern in medical practice. Hepatitis E is a potential threat among transfusion-transmitted infections. In resource poor settings and in endemic countries, parenteral transmission can occur at an increased rate and leads to subclinical infection. Currently Hepatitis E virus screening is not mandatory in many countries. This can possibly endanger the population.
\end{abstract}

Materials and Methods: We aimed at estimating the seroprevalence of HEV antibodies (IgG) among healthy blood donors in Chennai, South India. A prospective study was conducted among 142 blood donors from January 2016 to November 2016 in a tertiary care teaching hospital. Serum anti HEV IgG antibody was detected by Enzyme Linked Immuno Sorbent Assay (ELISA).

Results: Out of 142 samples, 19/142 (13.38\%) showed positivity for IgG antibodies for HEV.

Conclusion: This study showed the importance of screening for HEV, as there is increased rate of positivity among the blood donors in our study population.

Keywords: Hepatitis E, Parenteral Transmission, Blood Transfusion, Maternal Mortality, HEV IgG

\section{Introduction}

Hepatitis E is an enterically transmitted infectious virus, which causes acute self-limiting hepatitis. ${ }^{[1]}$ Initially it was considered as only water borne outbreak infection, now it has been proven that there are other modes of transmissions like zoonotic transmission, person-to-person transmission and through blood transfusion. ${ }^{[1]}$ Transfusion transmitted infections (TTI) are one among the major risks during blood transfusion. ${ }^{[2]}$ Among them, most commonly screened infections during blood and blood products transfusion in health care centers are as follows: Human immuno deficiency virus (HIV), Hepatitis B virus (HBV), Hepatitis $\mathrm{C}$ virus (HCV), syphilis and malaria. Other least common infections screened are Toxoplasmosis, Leishmaniasis and Hepatitis E virus (HEV). ${ }^{[3]}$ Developed countries have a constant vigilance in the estimation of prevalence of transfusion related $\mathrm{HEV}$ infections. It was estimated that 80,000 to $1,00,000 \mathrm{HEV}$ infections had occurred due to transfusion in England in 2013, with seroprevalence rate of $6.8 \%$ and annual incidence rate of $0.35 \% .{ }^{[4]}$ Studies in developing countries like India are very limited and only little evidence is available till now. In a study conducted among blood donors in Pune, $1.5 \%$ of HEV RNA was estimated during the year 2000 and 3.7\% during the year 2004. ${ }^{[5,6]}$ Blood transfusions are carried out in critically ill cases that include solid organ transplantation, pregnancy, hematological disorders and neoplasm. Hepatitis E, even though most commonly causes self limiting diseases, in the above said critically ill and immunocompromised cases, it leads to more severe presentations that may end up in chronic hepatitis and cirrhosis. Though acute morbidity due to transmission of HEV infection through blood transfusion is rare and supporting evidences are still lacking, studies need to be explored in all developing countries to know the real burden of transfusion transmitted HEV infections. ${ }^{[7]}$ Hence we aimed at estimating the seroprevalence of HEV IgG antibodies among healthy blood donors in our tertiary hospital, Chennai, South India.

\section{Materials and Methods}

A prospective study was conducted in the Department of transfusion medicine in a tertiary care teaching hospital in Chennai, South India. Institutional ethical committee approval was obtained and the serum samples were anonymized. By simple random sampling, 142 samples of the healthy donors were chosen as study population during the study period of January to November 2016. Serum anti HEV IgG antibody was detected by Enzyme Linked ImmunoSorbent Assay (ELISA). Third generation enzyme immune assay for the detection of IgG antibodies to Hepatitis E virus kit (Diagnostic Bioprobes Srl Via G. Carducci nº 2720099 Sesto San Giovanni - Italy) was used and procedure was done as per manufacturer instructions. 
The sensitivity and specificity of the kit is $100 \%$. The positive cases were retested in duplicate. The results were tabulated in MS office Excel 2016 and analyzed using SPSS software.

\section{Results}

The study population that included 142 samples showed predominant gender distribution of 141 males and 1 female donor. The range of age is from 18 years to 51 years with a mean age of 25 years. Age distribution was analyzed by stratification of age group into $18-20$ years $(33.09 \%)$, $21-30$ years $(49.29 \%), 31-40$ years $(13.38 \%), 41-50$ years $(3.52 \%)$ and $51-60$ years $(0.7 \%)$.

Out of 142 samples, 19/142 (13.38\%) showed positivity for anti-IgG antibodies for HEV. The distribution of HEV positive cases based on age stratification is depicted in Figure 1.

Table 1: Comparative evidence of seroprevalence of Hepatitis E among blood donors in different countries.

\begin{tabular}{|c|c|c|c|c|c|}
\hline $\begin{array}{l}\text { Study } \\
\text { Place }\end{array}$ & $\begin{array}{l}\text { Study } \\
\text { Year }\end{array}$ & Methodology & Detection & $\begin{array}{c}\text { Sero- } \\
\text { prevalence }\end{array}$ & Ref \\
\hline Spain & 1998 & ELISA & HEV IgG & 2.8 & (13) \\
\hline Pune,India & 2000 & PCR & HEV RNA & 1.5 & $(5)$ \\
\hline United States & 2002 & ELISA & HEV IgG & 18.3 & $(14)$ \\
\hline Saudi Arabia & 2004 & ELISA & HEV IgM & 8.96 & $\begin{array}{l}\text { (6)25 of whom were transfused with } 107 \text { blood } \\
\text { units, while the other } 25 \text { did not receive any } \\
\text { transfusions. InRESULTS: In our retrospective } \\
\text { study, markers of acute HEV infection (IgM anti- } \\
\text { HEV and HEV RNA }\end{array}$ \\
\hline Pune,India & 2007 & PCR & HEV RNA & 0 & $(18)$ \\
\hline South west France & 2007 & ELISA & HEV IgG & 16.6 & $\begin{array}{l}\text { (17) } 19.1 \% \text { of rural donors and } 14.2 \% \text { of urban } \\
\text { donors had anti-HEV antibodies }(P=0.13\end{array}$ \\
\hline Japan & 2007 & ELISA & HEV IgG & 7.1 & $\begin{array}{l}\text { (19)serum samples were collected from } 6700 \\
\text { voluntary blood donors with an elevated alanine } \\
\text { aminotransferase (ALT }\end{array}$ \\
\hline Gujarat, India & 2012 & ELISA & HEV IgM & 4.78 & $(12)$ \\
\hline Southeast England & 2012 & PCR & HEV RNA & 0.04 & $\begin{array}{l}\text { (7)but is probably widespread, and the virus has } \\
\text { been detected in pooled plasma products. HEV- } \\
\text { infected donors have been retrospectively identified } \\
\text { through investigation of reported cases of possible } \\
\text { transfusion-transmitted hepatitis E. The frequency } \\
\text { of HEV transmission by transfusion and its outcome } \\
\text { remains unknown. We report the prevalence of } \\
\text { HEV RNA in blood donations, the transmission of } \\
\text { the virus through a range of blood components, and } \\
\text { describe the resulting morbidity in the recipients.I } \\
\text { nMETHODS: From Oct } 8,2012 \text {, to Sept } 30 \text {, } 2013 \text {, } \\
225,000 \text { blood donations that were collected in } \\
\text { southeast England were screened retrospectively } \\
\text { for HEV RNA. Donations containing HEV were } \\
\text { characterised by use of serology and genomic } \\
\text { phylogeny. Recipients, who received any blood } \\
\text { components from these donations, were identified } \\
\text { and the outcome of exposure was ascertained.I } \\
\text { nFINDINGS: } 79 \text { donors were viraemic with } \\
\text { genotype } 3 \text { HEV, giving an RNA prevalence of one } \\
\text { in } 2848 \text {. Most viraemic donors were seronegative } \\
\text { at the time of donation. The } 79 \text { donations had } \\
\text { been used to prepare } 129 \text { blood components, } 62 \\
\text { of which had been transfused before identification } \\
\text { of the infected donation. Follow-up of } 43 \text { recipients } \\
\text { showed } 18 \text { ( } 42 \%\end{array}$ \\
\hline
\end{tabular}




\begin{tabular}{|l|c|c|c|c|l|}
\hline $\begin{array}{l}\text { Study } \\
\text { Place }\end{array}$ & $\begin{array}{c}\text { Study } \\
\text { Year }\end{array}$ & Methodology & Detection & $\begin{array}{c}\text { Sero- } \\
\text { prevalence }\end{array}$ & Ref \\
\hline Germany & 2013 & ELISA & HEV IgG & 6.8 & $\begin{array}{l}\text { (4)incidence, and viremia in blood donors for the } \\
\text { assessment of risk of transfusion-transmitted (TT }\end{array}$ \\
\hline Central Italy & 2014 & ELISA & HEV IgG & 49 & $(20)$ \\
\hline & & & HEV IgM & 0.63 & \\
\hline & & & HEV RNA & 0.63 & \\
\hline Punjab, India & $\begin{array}{c}\text { Not } \\
\text { given }\end{array}$ & ELISA & HEV IgG & 10.7 & $(21)$ \\
\hline Chennai, India & 2016 & ELISA & HEV IgG & 13.38 & Current study \\
\hline
\end{tabular}

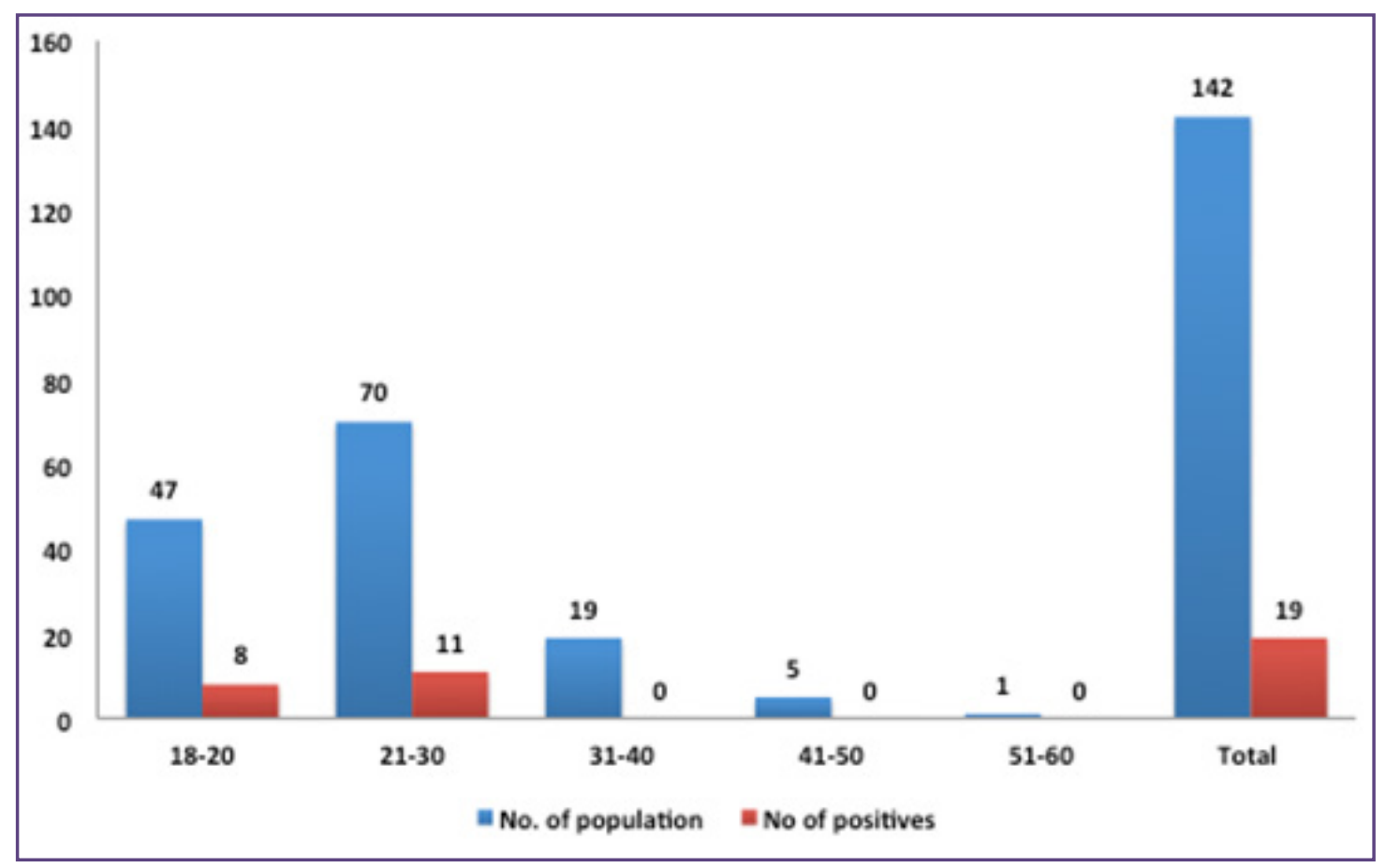

Fig. 1: Age wise distribution of study population and HEV seropositivity.

\section{Discussion}

In our study, among a total of 142 voluntary blood donors screened for HEV antibodies, $13.38 \%$ showed seropositivity. Gender preponderance for HEV infection cannot be concluded from our study, as there is male dominance in study population. However certain studies conducted at Japan and Iran have shown a male preponderance. In contrary, studies from France and Brazil have shown no difference among gender distribution in HEV seroprevalence. ${ }^{[8,9,10]}$ Age stratification has shown that majority of the positives are amongst younger age group $8 / 47(17.02 \%)$ among $18-20$ years followed by $11 / 70$ (15.71\%) among 21-30 years. None of the population above the age group of 31 years showed positivity. This may be contrary to the study conducted in western India, which showed increased positivity among older age groups supported by studies in USA and Denmark..$^{[1,12,13,14]}$ This may be due to decreased number of study population in age group more than 31 years.

Seroprevalence rate in our study is comparable with the higher prevalence as seen in southwest France and England. ${ }^{[15,16,17]}$ Few Indian studies have shown lesser seroprevalence rates of $1.5 \%$ and $3.7 \%$, but the methodology used was polymerase chain reaction, which detected HEV RNA. ${ }^{[5,6]}$ Comparison of prevalence rates among different studies are represented in Table 1.

The reasons behind these variations may be due to different sample size, different age groups and due to different methodology used that included serological methods and molecular methods. 
Seroprevalence rates are detected based on the presence of anti-HEV IgG in blood. Though the duration of persistence of anti-HEV IgG in blood after exposure is not certain, it mainly depend upon immune status of individual and other factors. Antibody levels are in peak during acute phase of illness and it may persist up to a maximum of 12 years or even more. ${ }^{[22]}$ Clinical risk of transmission of infection can be evidenced only by detection of viremia either in asymptomatic form or in subclinical presentation. Studies estimating seroprevalence helps in estimating the burden of HEV. However only HEV RNA detection aids in identifying viremic cases and transmission related risk could be estimated with increased specificity. ${ }^{[23]}$ Since molecular methods are limitedly used only for epidemiological studies due to cost factor; serological methods using more sensitive and specific kits (anti HEV IgM and anti HEV IgG) is mandatory in all health care centers.

Limitations of our study are small sample size, increased distribution of younger age groups in study population and molecular method couldn't be used due to increased cost. Future plan has been proposed to conduct studies overcoming the above limitations.

\section{Conclusion}

The above study throws light about screening for HEV in blood donors in general. Though little knowledge is available about HEV transmission risk during blood transfusion, in endemic countries it is advisory to screen the blood and blood products for HEV for effective prevention. More longitudinal studies need to be conducted in all health care centers to estimate the burden of HEV among Indian population, so that a national policy can be implemented to screen and prevent transmission of HEV during blood transfusion.

\section{References}

1. Khuroo MS, Khuroo MS, Khuroo NS. Transmission of Hepatitis E Virus in Developing Countries. Viruses. 2016 Sep 20;8(9).

2. Irshad M, Sharma Y, Dhar I, Singh J, Joshi Y-K. Transfusiontransmitted virus in association with hepatitis A-E viral infections in various forms of liver diseases in India. World J Gastroenterol. 2006 Apr 21;12(15):2432-6.

3. Pallavi P, Ganesh CK, Jayashree K, Manjunath GV. Seroprevalence and trends in transfusion transmitted infections among blood donors in a university hospital blood bank: a 5 year study. Indian J Hematol Blood Transfus Off J Indian Soc Hematol Blood Transfus. 2011 Mar;27(1):1-6.

4. Juhl D, Baylis SA, Blümel J, Görg S, Hennig H. Seroprevalence and incidence of hepatitis E virus infection in German blood donors. Transfusion (Paris). 2014 Jan;54(1):49-56.
5. Arankalle VA, Chobe LP. Retrospective analysis of blood transfusion recipients: evidence for post-transfusion hepatitis E. Vox Sang. 2000;79(2):72-4.

6. Khuroo MS, Kamili S, Yattoo GN. Hepatitis E virus infection may be transmitted through blood transfusions in an endemic area. J Gastroenterol Hepatol. 2004 Jul;19(7):778-84.

7. Hewitt PE, Ijaz S, Brailsford SR, Brett R, Dicks S, Haywood $\mathrm{B}$, et al. Hepatitis E virus in blood components: a prevalence and transmission study in southeast England. Lancet Lond Engl. 2014 Nov 15;384(9956):1766-73.

8. Anti Hepatitis E Virus Seropositivity in a Group of Blood Donors (PDF Download Available) [Internet]. [cited 2017 Jan 24]. Available from: https://www.researchgate. net/publication/237261115_Anti_Hepatitis_E_Virus Seropositivity_in_a_Group_of_Blood_Donors

9. Bortoliero AL, Bonametti AM, Morimoto HK, Matsuo T, Reiche EMV. Seroprevalence for hepatitis E virus (HEV) infection among volunteer blood donors of the Regional Blood Bank of Londrina, State of Paraná , Brazil. Rev Inst Med Trop Sao Paulo. 2006 Apr;48(2):87-92.

10. Takahashi M, Tamura K, Hoshino Y, Nagashima S, Yazaki Y, Mizuo H, et al. A nationwide survey of hepatitis E virus infection in the general population of Japan. J Med Virol. 2010 Feb;82(2):271-81.

11. Daniel HDJ, Warier A, Abraham P, Sridharan G. Age-wise exposure rates to hepatitis e virus in a southern Indian patient population without liver disease. Am J Trop Med Hyg. 2004 Nov;71(5):675-8.

12. Gajjar MD, Bhatnagar NM, Sonani RV, Gupta S, Patel T. Hepatitis E seroprevalence among blood donors: A pilot study from Western India. Asian J Transfus Sci. 2014 Jan;8(1):29-31.

13. Mateos ML, Camarero C, Lasa E, Teruel JL, Mir N, Baquero F. Hepatitis E virus: relevance in blood donors and other risk groups. Vox Sang. 1998;75(4):267-9.

14. Meng XJ, Wiseman B, Elvinger F, Guenette DK, Toth TE, Engle RE, et al. Prevalence of antibodies to hepatitis $\mathrm{E}$ virus in veterinarians working with swine and in normal blood donors in the United States and other countries. J Clin Microbiol. 2002 Jan;40(1):117-22.

15. Dalton HR, Stableforth W, Thurairajah P, Hazeldine S, Remnarace R, Usama W, et al. Autochthonous hepatitis $\mathrm{E}$ in Southwest England: natural history, complications and seasonal variation, and hepatitis $\mathrm{E}$ virus IgG seroprevalence in blood donors, the elderly and patients with chronic liver disease. Eur J Gastroenterol Hepatol. 2008 Aug;20(8):784-90.

16. Ijaz S, Arnold E, Banks M, Bendall RP, Cramp ME, Cunningham R, et al. Non-travel-associated hepatitis E in England and Wales: demographic, clinical, and molecular epidemiological characteristics. J Infect Dis. 2005 Oct 1;192(7):1166-72. 
17. Mansuy JM, Legrand-Abravanel F, Calot JP, Peron JM, Alric L, Agudo S, et al. High prevalence of anti-hepatitis E virus antibodies in blood donors from South West France. J Med Virol. 2008 Feb;80(2):289-93.

18. Anand AC, Singh KJ, Sharma P, Kumar S, Gupta RM. Incidence of Hepatitis E Virus Infection in Recipients of Blood or Blood Products Transfusion. Med J Armed Forces India. $2010 \mathrm{Jul} ; 66(3): 204-7$.

19. Gotanda Y, Iwata A, Ohnuma H, Yoshikawa A, Mizoguchi $\mathrm{H}$, Endo K, et al. Ongoing subclinical infection of hepatitis $\mathrm{E}$ virus among blood donors with an elevated alanine aminotransferase level in Japan. J Med Virol. 2007 Jun 1;79(6):734-42.
20. art22532.pdf [Internet]. [cited 2017 Jan 21]. Available from: http://www.eurosurveillance.org/images/dynamic/EE/ V21N30/art22532.pdf

21. Original Article (Ravinder) - Vol1Issue3_41OA.pdf [Internet]. [cited 2017 Jan 21]. Available from: http:// aimdrjournal.com/pdf/Vol1Issue3_41OA.pdf

22. Retrospective serological analysis of hepatitis E patients: a long-term follow-up study. [Internet]. [cited 2017 Jan 24]. Available from: http://www.medscape.com/medline/ abstract/10607264

23. Bajpai M, Gupta E. Transfusion-transmitted hepatitis E: Is screening warranted? Indian J Med Microbiol. 2011 Oct 1;29(4):353.

*Corresponding author:

Jamunarani Srirangaramasamy, Associate Professor, Department of Pathology, Tagore Medical college and Hospital, Rathinamangalam,

Chennai-600127, Tamilnadu, India

Phone: +91 9884060903

Email: jamunapath@tagoremch.com

Date of Submission : 16.03.2017

Financial or other Competing Interests: None. 